\title{
PIPELINES AND THE FEDERAL TRANSPORTATION POWER
}

\author{
JOHN BISHOP BALLEM, Q.C.*
}

The author examines the recent spate of constitutional cases involving hydrocarbon pipelines which has led to the emergence of the "essential" test as the governing principle determining whether or not a related facility is an integral part of or is necessarily incidental to a federal pipeline undertaking. These cases suggest that if a facility is "essential" (rather than being merely helpful or beneficial) to a federal pipeline undertaking, it will be deemed to have the necessary nexus with the undertaking and to be an integral part of it. The author then applies the "essential" test to jurisdictional questions surrounding several major pipeline facilities in Western Canada, including the NOVA network in Albersa. The author concludes that the "essential" test has much to recommend it. It corresponds more closely to the realities of the situation than some other factors considered by courts in the past. While it unavoidably involves some judgmental elements, the necessary facts can be presented in evidence and the test lends itself to the application of common sense. Finally, from a philosophical perspective, it seems appropriate that something which is essential to the operation of an undertaking should be treated as an integral part of that undertaking.
L'auteur examine la récente avalanche de cas constitutionnels relatifs aux pipelines et qui a entraîné l'émergence du critère ressentielv principe directeur servant d̀ déterminer si une installation connexe fait partie intégrante d'une entreprise fédérale de pipelines ou lui est nécessairement accessoire. Ces cas suggèrent que si une installation donnée est ressentielle» (plutôt que simplement utile ou bénéfique) à une entreprise fédérale de pipelines, on estimera qu'elle a le lien nécessaire avec l'exploitation pour en faire partie intégrante. L'auteur applique ensuite ce critère "essentiel aux questions juridictionnelles relatives d plusieurs réseaux majeurs de pipelines dans l'Ouest du Canada, dont le réseau NOVA en Alberta. L'auteur conclut que le critère cessentiel présente de nombreux avantages. Il colle plus étroitement aux réalités que certains autres facteurs considérés par les tribunaux dans le passé. S'il fait inévitablement appel au discernement, les faits nécessaires peuvent être présentés comme preuve et le critère se prête à l'application du bon sens. Finalement, d'un point de vue philosophique, il semble approprié qu'une chose essentielle d l'exploitation d'une entreprise soit traitée comme en faisant partie intégrante.

\section{TABLE OF CONTENTS}

I. INTRODUCTION

II. THE BASIS FOR FEDERAL JURISDICTION

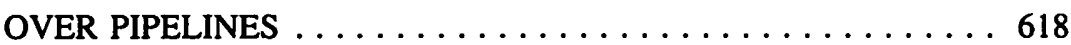

III. THE DEVELOPMENT OF THE "ESSENTIAL"

TEST OF JURISDICTION ................. 623

IV. THE PREDICTIVE VALUE OF THE "ESSENTIAL TEST" APPLICATION TO EXISTING PIPELINE FACILITIES . . . . 627

V. THE "ESSENTIAL" TEST AND RELATED

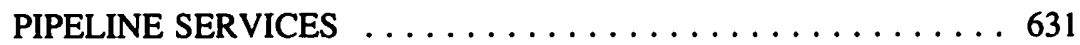

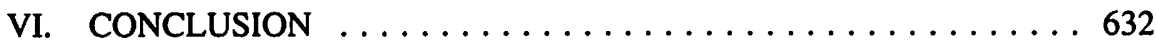

\section{INTRODUCTION}

While transportation may not be the engine that drives our economy, it is certain that the economy could not function without it. Moreover, this dependence on the transportation of people and goods increases with each passing day. By way of example,

Member of the Alberta Bar, Calgary. 
the current shortage of pipeline capacity has severely limited the market for western Canadian natural gas, with the result that prices are depressed and exploration activities have been significantly reduced. Thus it is not surprising that the federal power over transportation has received a considerable amount of judicial attention in recent years.

Interestingly enough, the cases involving the transportation power arise not from jurisdictional disputes between the two levels of government, but rather because of private interests seeking to achieve their own private agendas. For example, the cases involve petrochemical companies wanting access to a pipeline, ${ }^{1}$ farmers not wanting electrical transmission towers erected on their property, ${ }^{2}$ an industrial fertilizer plant seeking to construct its own natural gas pipeline connection, ${ }^{3}$ and a municipality attempting to prevent the transportation of certain natural gas liquids by pipeline. ${ }^{4}$ Pipelines in particular have been given a judicial workout, so much so that it is now possible to identify with some certainty the principles the courts will rely on to determine who has jurisdiction over a pipeline. ${ }^{5}$ While each case will be decided on its own facts, the courts have now told us what facts they consider to be determinative. Thus it seems both useful and timely to revisit the federal power over pipelines, particularly since pipelines are playing an increasingly important, and often hotly contested, role in the economy.

\section{THE BASIS FOR FEDERAL JURISDICTION OVER PIPELINES}

There are three ways in which a pipeline or related facilities can come within federal jurisdiction:

(i) by comprising an undertaking which clearly extends beyond provincial boundaries;

(ii) although not in itself an extraprovincial undertaking, by being so closely connected with that undertaking so as to form part of it; or

(iii) by being the subject of a declaration that it is a work for the general advantage of Canada or for the advantage of two or more provinces under s. 92(10)(c) of the Constitution Act, $1867 .^{\circ}$

Dome Petroleum Lid. v. The National Energy Board (1987) 73 N.R. 135, C.E.L.S. 10-5149 (F.C.A.). Fulton v. Energy Resources Conservation Board et al [1981] I S.C.R. 153, [1981] 4 W.W.R. 236, 118 D.L.R. (3d) 577, 26 A.R. 542, 34 N.R. 504 affirming [1980] 3 W.W.R. 176, 109 D.L.R. (3d) 189, 19 A.R. 616 (S.C.C.).

3. In re the National Energy Board Act (Jurisdiction over Cyanamid Pipeline Inc.'s Bypass Pipeline) [1988] 2 F.C. 196, 81 N.R. 241, 48 D.L.R. (4th) 596 (F.C.A.) leave to state a constitutional question granted (1988) 49 D.L.R. (4th) viin (S.C.C.). The appeal was subsequently abandoned.

4. Flamborough v. National Energy Board, Interprovincial Pipe Line Lid. and A.G. Canada (1984) 55 N.R. 95 (F.C.A) leave to appeal to S.C.C. refused (1984) 58 N.R. 79n (S.C.C.).

I first addressed the question of jurisdiction over pipelines in Ballem, Constitutional Validity of Provincial Oil and Gas Legislation (1963), 41 Can. Bar Rev. 199. See also McNaim, Transportation. Communication and the Constitution: The Scope of Federal Jurisdiction (1969), 47 Can. Bar Rev. 355.

30 \& 31 Victoria, c. 3 (U.K.). 
I do not propose to deal with the declaratory power of the federal government under s. $92(10)(c)$, since that matter is reasonably straightforward, with the constitutional issues lying within a narrow compass. Basically, all that is required is that there be a work and a Parliamentary declaration. ${ }^{\text {? }}$

The federal power over pipelines under categories (i) and (ii) is to be found in the exceptions to the provincial powers enumerated in s. 92(10)(a), which matters so excepted are transferred to federal jurisdiction by the operation of s. 91(29). The combined effect of these two subsections is to confer on the federal government the power to make laws in relation to:

Lines of steam or other ships, railways, canals, telegraphs and other works and undertakings connecting the province with any other or others of the provinces, or extending beyond the limits of the province.

The starting point for an analysis under category (i) is the judicial finding in Campbell-Bennett Ltd. v. Comstock Midwestern Ltd. ${ }^{8}$ that interprovincial or international pipelines (to avoid needless repetition I will refer to both of these as extraprovincial pipelines) fall within the umbrella of "other works and undertakings", even though they are not mentioned specifically in s. 92(10)(a). This finding alone is sufficient to place the major Canadian pipeline systems, such as TransCanada PipeLines Ltd. ("TCPL") in the case of natural gas, and Interprovincial Pipe Line Company ("IPL") in the case of liquid hydrocarbons, firmly in the federal camp as they unquestionably connect provinces and extend beyond the limits of a province. Thus, the major pipeline systems which fall within category (i) occasion little difficulty. Indeed, with the exception of the Comstock case, which involved an unsuccessful attempt to enforce a lien under the British Columbia Mechanics' Lien Act against the property of the Trans Mountain Oil Pipe Line Company' and, in a minor way, the Flamborough case, ${ }^{9}$ federal jurisdiction over such undertakings has not been challenged in the courts.

Facilities which fall within category (ii), however, are another matter and are the subject of much judicial analysis. Certain facilities such as storage terminals, spur lines, injection facilities, and gathering lines may be situated entirely within the bounds of one province, yet connect in some fashion with a major transmission system. Such situations present the courts with the complex and often difficult question as to whether the connection or "nexus" is such as to cause the facilities to lose their local undertaking

7. Luscar Collieries Limited v. C.N.R. [1927] A.C. 925, [1927] 3 W.W.R. 454, [1927] 4 D.L.R. 85, 33 C.R.C. 399 (p.c.) affirming [1925] S.C.R. 460, [1925] 3 D.L.R. 225, 31 C.R.C. 267. At page 480 of [1925] S.C.R. 460 Mignault, J. said, "Parliament is the sole judge of the advisability of making this declaration as a matter of policy which it alone can decide." It should also be noted that s. 92(10)(c) refers only to "Works" so that only a physical work can be the subject of a declaration. However, a declaration can affect works not yet in existence so long as they are adequately defined; Jorgenson v. Attorney General for Canada and Attorney General for Alberta [1971] S.C.R. 725 , [1971] 3 W.W.R. 149, 18 D.L.R. 297 (S.C.C.); (1970) 75 W.W.R. 259, 12 D.L.R. (3d) 652 (Man. C.A.).

8. Campbell-Bennett Lid. v. Comstock Midwestern Lid., [1954] S.C.R. 207, [1954] 3 D.L.R. 481, (S.C.C.); [1953] 3 D.L.R. 594, 8 W.W.R. (N.S.) 683 (B.C.C.A.).

9. Flamborough, supra, note 4. 
characterization and become a part of the federal undertaking and thus subject to the federal transportation power.

The answer is to be found in the basic question posed by the Privy Council in Attorney General of Canada et al v. Israel Winner et al ${ }^{10}$ as to whether the "undertaking in question is in fact one and indivisible". That question has been expressed in many different ways, and the courts have followed several different routes to answer it, but in the final analysis that is what the issue boils down to. Over the years courts have employed a number of seemingly different tests to find the answer to this basic question. Recently, however, the courts have narrowed the range of the applicable tests and have concentrated on identifying the general principles that underlie the tests, regardless of how those tests may be expressed.

The Winner case, which has been described as possibly the leading case in this area," involved a licence issued by a provincial board allowing an American concern to operate motor buses from Boston through New Brunswick to Nova Scotia, but not to embus and debus passengers between points that were entirely within the province of New Brunswick. Winner defied this restriction in the licence and continued to embus and debus passengers within the province of New Brunswick. The Supreme Court of Canada found that the embusing and debusing of passengers within the province could be severed as not being essential but, rather, ancillary to the extraprovincial work or undertaking and, therefore, such purely provincial traffic was within the province's jurisdiction. This finding was reversed by the Privy Council which held:

The question is not what portions of the undertaking can be stripped from it without interfering with the activity altogether, it is rather what is the undertaking which is in fact being carried on. Is there one undertaking, and as part of that one undertaking does the respondent carry passengers between two points both within the province, or are there two?

Under the circumstances of the Winner case, the Privy Council found that the undertaking was one and indivisible and the fact it might have been carried on differently (i.e. by separating the provincial and extraprovincial traffic) did not make it any less indivisible. Subsequently, the federal government delegated the regulatory power that had been conferred on it by the Privy Council back to the provincial board. ${ }^{12}$

The Winner rationale was first applied to a pipeline situation by a regulatory tribunal rather than a court. Nonetheless, the Board of Transport Commissioners in the Westspur Pipeline case $^{13}$ enunciated the relevant principles and, indeed, foreshadowed the guidelines later laid down by Dickson, J. (as he then was) and Estey, J. in the two (N.S.) 657, (P.C.); [1951] S.C.R. 889, [1951] 4 D.L.R. 529 (S.C.C.), [1950] 3 D.L.R. 207 (N.B. S.C.A.D.).

11. Flamborough, supra, note 4, Mahoney, J.

12. See Ballem, Delegation By Parliament To A Provincial Board, (1954), 32 Can. Bar Rev. 788.

13. Re: Westspur Pipeline Company Gathering System (1957), 76 C.R.T.C. 158. 
Telecom cases. ${ }^{14}$ In Westspur, a federally incorporated company, which operated an extraprovincial pipeline, applied to the federal board for leave to sell to a subsidiary company its facilities making up its gathering system within the province of Saskatchewan. The gathering system collected oil from the oil fields and delivered it to Westspur's extraprovincial mainline. The Board listed at least five factors that must be considered in determining whether the gathering facilities formed part of the extraprovincial undertaking. The five factors were:

(1) physical connection;

(2) ownership;

(3) method of operation;

(4) purpose of the gathering lines; and

(5) whether the gathering lines in question are part of the undertaking of Westspur.

While the Board stated that each of the five factors must be considered, it found that physical connection and ownership ${ }^{15}$ were not determinative. With respect to the method of operation, the Board was unable to find that the proposed sale to a subsidiary company would result in any real separation of the gathering aspect from the trunk line aspect.

In examining the "purpose" factor, which is remarkably similar to the "essential" test currently favoured by the courts, the Board found it was obvious that "while gathering lines are required for the benefit of the producers, they are equally required as feeders to the trunk lines". The Board's finding that the undertaking was, in fact, one and indivisible seemed to flow directly from its reasoning on the "purpose" test.

While the Board's decision in Westspur is both illuminating and correct, it is of persuasive value only and cannot be treated as a precedent. When it comes to judicial decisions, a great many of the cases on what constitutes part of a federal undertaking arise out of situations which involve labour relations, i.e. are the workers subject to provincial or federal labour legislation? In order to answer this question, the court must first address the issue of federal jurisdiction over the work, undertaking or business itself. The Stevedores case, ${ }^{16}$ which found that a company whose operations consisted exclusively of loading and unloading ships fell within federal jurisdiction, laid down the following test:

Northern Telecom Ltd. v. Communications Workers of Canada et al (Telecom I), [1980] 1 S.C.R. 115; [1977] 2 F.C. 406 (F.C.A.); (Telecom II), [1983] 1 S.C.R. 733; [1982] 1 F.C. 191 (F.C.A.). In Telecom I the Supreme Court refused to make a finding on the constitutional issue because the evidence did not present enough "constitutional facts".

15. Luscar Collieries Ltd., supra note 7.

16. In the matter of a Reference as to the Validity of the Industrial Relations and Disputes Investigations Act, R.S.C. 1952, c. 152, [1955] S.C.R. 529, [1955] 3 D.L.R. 721 (S.C.C.). 
If, therefore, the work of stevedoring, as performed under the foregoing contracts, is an integral part or necessarily incidental to the effective operation of these lines of steamships, legislation in relation thereto can only be competently enacted by the Parliament of Canada. ${ }^{17}$

The two Telecom cases ${ }^{18}$ involved a company which provided telephone equipment installation service to its controlling shareholder, which services accounted for $90 \%$ of its workload. In Telecom I, Dickson, J. enunciated four guidelines to be used in determining whether a facility or service is "an integral part or necessarily incidental to" a federal undertaking. These guidelines were restated by Estey, J., after a detailed review of the existing authorities, in Telecom II, wherein the majority found that the labour relations of Telecom's installers fell within federal jurisdiction. Estey, J. wrote that:

The principal and dominant consideration in determining the application of the principle enunciated in the Stevedores case is an examination of 'the physical and operational connection' between the installers of Telecom and the federal core undertaking, the telephone network, and in particular the extent of the involvement of the installers in the establishment and operation of the Federal undertaking as an operating system."

Having identified the "physical and operational connection" as the "principal and dominant consideration", Estey, J. went on to state that the court must consider "as a subsidiary but not unimportant consideration" the importance of the work done by Telecom or Bell as compared to other customers of Telecom and the corporate interrelationship between Bell and Telecom. It is important to bear in mind that it is the physical and operational connection that has been identified as the principal and dominant consideration while the other factors are treated as subsidiary considerations.

When dealing with pipeline facilities in category (ii), the approach taken in Telecom $I I$ would appear to represent the appropriate starting point for the analysis. In fact, Urie, $\mathrm{J}$. in the Bernshine case ${ }^{19}$ described Telecom II as the definitive judgment and commented that "no useful purpose would be served in further discussion of those and other decisions reviewed by Mr. Justice Estey".

As we will see, the "physical and operational connection" aspect has been further elaborated in two recent decisions at the Federal Court of Appeal level. Before examining these cases, however, it is instructive to look at a clear example of what does not meet the test for federal jurisdiction. In any analysis it is helpful to have a situation at the extreme end of the spectrum to establish the outer limits. The Empress Hotel case ${ }^{20}$ which is invariably cited by counsel arguing the provincial position, provides such an example. Victoria's famous Empress Hotel, although owned by the Canadian Pacific

17. Ibid. S.C.R., 568, Estey, J.

18. Telecom I and Telecom II, supra, note 14.

19. Bernshine Mobile Maintenance Lid. v. Canada Labour Relations Board, [1986] 1 F.C. 422, 22 D.L.R. (4th) 748, (F.C.A.).

20. C.P.R. v. Attorney General for British Columbia and Attorney General for Canada [1950] I W.W.R. 220; [1950] A.C. 122, 64 C.R.T.C. 266; [1950] 1 D.L.R. 721 affirming [1948] S.C.R. 373; [1948] 3 D.L.R. 417 which affirmed [1947] 1 W.W.R. 927, 61 C.R.T.C. 49, [1947] 2 D.L.R. 723. 
Railway, carries on a general hotel business. The issue arose because the C.P.R. disputed the applicability of the British Columbia Hours of Work Act to employees of the hotel. One of the grounds was that the hotel was part of the federal railway undertaking. The Supreme Court held that while the hotel might make the business of the company's extraprovincial railway more effective, that was not sufficient to make it part of the railway undertaking. However, as the Court pointed out:

...it may be that, if the Appellant wishes to conduct a hotel solely or even principally for the benefit of travellers on its system, that hotel would be part of its railway undertaking. ...

\section{THE DEVELOPMENT OF THE "ESSENTIAL" TEST OF JURISDICTION}

In the cases involving pipelines, however, the connection between the facility and the federal undertaking will normally be much closer than the connection between a hotel and a railway system. Thus the courts will be faced with the need to make a much more detailed examination of the facts. In looking at what Dickson, J., in Telecom I, called the "constitutional facts", 21 i.e. those facts that focus on the constitutional issues in question, a court will pay attention to the findings of fact made by a regulatory tribunal. In the case of pipelines, the constitutional issue will frequently come before the courts by way of an appeal from the National Energy Board ("NEB") which will, in the first instance, have examined the facts and have made its own determination as to its jurisdiction. The courts must, course, arrive at their own conclusions, but in doing so, will take into consideration the "constitutional facts" as found by the regulatory tribunal. It is not unlike the way an appeal court treats findings of fact made by a trial judge as can be seen from this quote by Urie, $\mathrm{J}$. in the Bernshine case: ${ }^{22}$

As the trier of facts on matters peculiarly within its area of expertise and having had the advantage of seeing and hearing the witnesses, those findings of fact ought not to be lightly interfered with. ...it seems to me that the Board's findings of fact should not be found erroneous unless they were clearly wrong having regard to its members' background knowledge and experience in determining matters of this kind.

The "constitutional facts" in Flamborough ${ }^{23}$ were such as to allow the court to find that the facilities in question fell within category (i) and that the undertaking was one and indivisible. In the Flamborough case, IPL, unquestionably a federal undertaking, applied to the NEB for permission to modify Line 8, one of the many pipelines making up its system, so that it could carry specification propane from Sarnia, Ontario to other points within Ontario and to construct the necessary delivery facilities near Flamborough, Ontario. The NEB's jurisdiction was challenged by the Municipality of Flamborough on the ground that, while the NEB had jurisdiction to entertain the application at the time of the hearing, since the pipeline in question was clearly part of the IPL work and undertaking, as soon as the NEB had approved the application to convert the line into one for the transportation of specification propane, that line ceased to be part of the IPL work and undertaking. The municipality contended that the specification propane to be

23. Flamborough, supra, note 4. 
transported in Line 8 was not the same substance as the natural gas liquid mixture transported though IPL's main transmission lines from Alberta to Sarnia. The argument ran that the transportation of that substance through Line 8 was an independent operation unrelated to the IPL work and undertaking.

Mahoney, J. went back to the 1954 Winner case and applied the test of what is the undertaking which is in fact being carried on. Under the circumstances of the Flamborough case, the Court found the specification propane that was to be transported through Line 8 was still the same material which was in the natural gas liquids stream transported from the west. The only change was that it had been separated into specification propane by removing the butane and condensate with which it had been mixed. Also the fact that it was necessary to isolate Line 8 from all crude oil connections so that it could carry specification propane did not mean that IPL was separating that line from its interprovincial operations. The Court found that IPL was doing what it was entitled to do in its interprovincial operations. Presumably, what the Court believed IPL was entitled to do was to transport hydrocarbons. This analysis led the Court to find that the modified Line 8 continued to be an integral part of the system operated by IPL and that the system was one undertaking from which the modified Line 8 was not to be severed.

It is interesting to compare the most recent Federal Court of Appeal pipeline decision in the Cyanamid case $\mathrm{s}^{24}$ with the result in Flamborough. In certain aspects the two cases parallel each other although the results were diametrically opposite. With the so-called "deregulation" of natural gas marketing in Canada, industrial users of gas in Ontario were free to contract directly with western producers to purchase their supply of gas and use the TCPL system to transport the gas to their plants. Cyanamid desired to go one step further by constructing a "bypass" pipeline connecting the TCPL mainline to its plant in Welland, Ontario. The proposed line would bypass the existing distribution system of Consumer's Gas which historically had delivered gas from the TCPL system to the plant. The line would be only $6.2 \mathrm{~km}$ in length and would be entirely within the province of Ontario. Cyanamid applied to the NEB for a certificate authorizing the construction of the proposed line, and also for an order directing TCPL to construct facilities to connect its main line with the proposed pipeline. The pipeline was to be owned and operated by Cyanamid.

The NEB heard argument on the jurisdictional issue and, after a lengthy analysis of judicial authorities, concluded that the proposed pipeline did in fact lie within federal

Cyanamid, supra, note 3. Prior to the NEB deciding that it had jurisdiction, the Ontario Energy Board found that it had exclusive jurisdiction over such pipelines and that jurisdictional finding was upheld by the Ontario Divisional Court. The matter was referred to the Ontario Court of Appeal by the Lieutenant-Governor in Council (Reference re Legislative Authority over ByPass Pipelines). The Ontario Court of Appeal deferred giving its decision until the Federal Court of Appeal had ruled on the basis that the latter was dealing with an actual application rather than an advisory opinion. After the Federal Court of Appeal decision was handed down the Ontario Court of Appeal stated it was in agreement with the decision that the pipeline in question was subject to provincial jurisdiction. Cyanamid obtained leave to appeal the Federal Court of Appeal decision to the Supreme Court, but elected not to proceed with it. 
jurisdiction. The NEB reached this conclusion by listing the various factors such as ownership, physical connection, operational integration, and functional integration, and concluded that, while none of the various factors were sufficient by themselves to confer jurisdiction upon the federal government, their combined effect added up to federal jurisdiction. Having determined that the pipeline was within federal jurisdiction, the NEB granted the orders as requested by Cyanamid. ${ }^{25}$

The jurisdictional issue was appealed to the Federal Court of Appeal and, in writing the judgment of the Court, MacGuigan, J. looked for governing principles to determine the issue. He had little difficulty in identifying what the NEB called the "essential test" as being determinative of the matter, citing a long list of authorities in support of that principle. ${ }^{26}$ These authorities led Justice MacGuigan to find that in order "for a work or undertaking to fall under federal jurisdiction under paragraph 92(1)(a), it must either be an interprovincial work or undertaking (the primary instance) or be joined to an interprovincial work or undertaking through a necessary nexus (the secondary instance)." The Court looked first at whether the proposed line could come within the "primary instance" (my category (i)) and applied Winner to find that it did not. The decision contained an interesting comment to the effect that the closest parallel to the Winner situation would be an application by TCPL to build and operate a bypass pipeline on its own. Since that was not the case, the proposed pipeline would have to meet the necessary nexus test if it was to come within federal jurisdiction. On the other hand, if TCPL had been the owner and operator, the situation, and presumably the result, would have been the same as Flamborough and the bypass line would have constituted part of TCPL's federal undertaking.

Applying the necessary nexus test to determine whether the proposed pipeline would be an integral part of the undertaking of TCPL, MacGuigan, J. found no such necessary connection. Indeed, he found the proposed bypass to be unnecessary and redundant, pointing out that TCPL already had a system which transported gas not only to the province of Ontario, but, with the aid of Consumers Gas, to Cyanamid's plant. TCPL had no need for anything more.

The "essential" test was clearly the determinative factor in Dome Petroleum Ltd. v. National Energy Board. ${ }^{27}$ In the Dome case, the issue revolved around underground storage caverns and related facilities located at Windsor, Ontario. The Cochin pipeline carried liquid hydrocarbons from Alberta to Windsor and the line also extended from

N.E.B. Decision 42, December 1986, In the Matter of an Application by Cyanamid Canada Pipeline Inc. C.E.L.S. 10-4449.

In the Matter of a Reference as to the Validity of the Industrial Relations and Disputes Investigation Act, supra, note 16; The Letter Carriers Union of Canada v. Canadian Union of Postal Workers et al, [1975] I S.C.R. 178, 40 D.L.R. (3d) 105, [1974] I W.W.R. 452 (S.C.C.); [1973] 1 W.W.R. 254 , 31 D.L.R. (3d) 508 (Sask. C.A.); Re Cannet Freight Cartage Lid. and Teamsters Local $4 / 9$ (1975), 11 N.R. 606, 60 D.L.R. (3d) 473 (F.C.A.); Canadian National Railway v. Nor-Min Supplies Limited, [1977] 1 S.C.R. 322, 66 D.L.R. (3d) 366 (S.C.C.); Construction Montcalm Inc. v. Minimum Wage Commission, [1979] 1 S.C.R. 754; [1976] R.D.T. 347 (Que. C.A.); [1975] C.A. 675; Northern Telecom Lid. v. Communications Workers of Canada et al, supra, note 14. 
Windsor to Sarnia. A second pipeline owned and operated by Dome called the Eastern Delivery System ("EDS"), confected Windsor to Samia as well as extending to a synthetic natural gas plant at Green Springs, Ohio. Both the Cochin and EDS pipelines were subject to federal jurisdiction. The Cochin pipeline system and the storage caverns were owned by Dome and four other companies that together made up the Ethane Shippers Joint Venture. The original purpose of the joint venture was to sell pure ethane to the gas plant in Ohio.

In a natural gas liquids pipeline such as Cochin, the different products are shipped in batches and a certain amount of contamination necessarily occurs in the pipeline where the batches interface. The contaminated interface material was separated out of the Windsor storage facility and stored in one of the underground caverns at Windsor. The NEB exercised jurisdiction over the interface cavern and that jurisdiction was not at issue. The jurisdictional issue involved the other storage caverns which were originally used in order to deliver pure ethane to the Ohio gas plant which required a constant supply of pure ethane but had no storage. When pure ethane was being batched down the Cochin system it was delivered into the EDS system at a point upstream of Windsor and transported to the gas plant. However, when either interface material or ethylene was passing the take-off point, the interconnection was closed and the batch continued on to Windsor. In order to meet the gas plant's requirement for a constant supply, pure ethane was drawn from the Windsor storage caverns and delivered through the EDS system to the gas plant.

These circumstances led Dome to argue that the storage caverns were not part of the Cochin system but were facilities used solely to enable the Ethane Joint Venture Shippers to perform their contract for the sale of a constant supply of pure ethane to the gas plant. However, the U.S. demand for ethane began to fall off and the contract with the Ohio plant was terminated after the NEB hearing was completed, but before the appeal was heard. In order to fill the unused pipeline capacity, the joint venture obtained an interim toll from the NEB for transporting propane from Edmonton to Windsor. The market for propane was in Sarnia, which meant it had to be transported from Windsor to Sarnia on the EDS system. However, potential propane shippers on Cochin, other than Dome, found themselves unable to utilize the propane transportation system because they did not have access to the Windsor storage. While transportation was available on Cochin from Edmonton to Windsor and on EDS from Windsor to Samia, the problem was in getting from Cochin into the EDS line at Windsor. Since the EDS pipeline had less capacity than the Cochin line, product to be transferred from Cochin to EDS at Windsor had to go in and out of storage at Windsor.

Dome relied on the fact that, at the time of the NEB hearing, the contract to supply ethane to the U.S. gas plant had not terminated, to argue that the NEB should have treated the factual situation as frozen in time and, accordingly, should have examined its jurisdiction in the light of the storage facilities being a means of allowing the joint venture to perform its contract to sell pure ethane. The Court refused to accept this argument, stating that the NEB was entitled to view the Cochin system and the storage caverns in the factual circumstances that had led to the application, namely, that propane would replace ethane and would be transported to Sarnia. The Court found that, indeed, the 
NEB was bound to take these future changes into account as it was being asked to fix a tariff for future application.

In dealing with the basic constitutional question, Mahoney, J., who wrote the unanimous decision of the Court, as he had in Flamborough, defined the issue as being one of fact, namely whether the storage caverns were an essential part of the Cochin system. After pointing out that common ownership is not determinative, he found that the "undertaking" of the pipeline was the transportation of products from Fort Saskatchewan in Alberta to Sarnia and intermediate points. As the Court pointed out, there must be some means of taking product from the line if the product in it is to move - without that there can be no transportation. Thus the function of the storage caverns differed markedly from that of the Empress Hotel in relation to Canadian Pacific's railway undertaking. The fact that the storage facilities were essential to the movement of product in the line made them an integral and essential part of the Cochin system.

\section{THE PREDICTIVE VALUE OF THE "ESSENTIAL" TEST - APPLICATION TO EXISTING PIPELINE FACILITES}

With the emergence of the "essential" test as the governing principle, one should be able to examine certain aspects of pipeline operations in Canada and predict their jurisdictional fate with some level of confidence. The Dome case did not deal with the injection facilities such as storage tanks for assembling batches of product because that issue was not before it. But a similar issue is now before the NEB because IPL has applied to the NEB for permission to construct certain liquid storage and injection facilities in the Edmonton area. These facilities will enable shippers to accumulate natural gas liquids and inject them into the IPL system for transportation to Sarnia and other points. The rationale of the Dome case would indicate that such facilities, although located entirely within Alberta, would easily pass the "essential" test and thus form part of the federal undertaking.

Another example of a provincial facility that could be transferred to federal jurisdiction is to be found in the use by TCPL of the mainline of Union Gas Limited, a local Ontario distributor, to transport gas from Dawn to Oakville, both points being within the Province of Ontario. Although this matter has never been put to the test, it would seem that the federal regulator would have jurisdiction over that portion of Union's mainline since it is the means by which a significant portion of the gas transported by TCPL from western Canada reaches eastern Canada. It should easily pass the "essential" test since it, like the storage caverns in Dome, constitutes a necessary link in the transportation system.

Then there is, of course, the perennial question of who has jurisdiction over the vast NOVA Corporation of Alberta ("NOVA") gathering system in Alberta. ${ }^{28}$ The NOVA network covers the province like a blanket, there are more than 850 receipt points and 150 delivery points on its system. NOVA, for all practical purposes, enjoys a monopoly in gathering natural gas within Alberta which is destined for export from the province. It 
delivers gas to TCPL at Empress, Alberta, where the connection between the two systems is pipe on pipe, a few hundred yards downstream of a meter station, and just inside the Alberta-Saskatchewan border. As it travels east, TCPL also takes delivery of a comparatively small amount of gas in Saskatchewan, but by far the largest percentage of its throughput originates in Alberta and is delivered by NOVA. The NOVA system delivers all of the gas that is transported by Foothills Pipe Lines (Yukon) Ltd. ("Foothills"), which moves gas within Alberta and delivers it to United States markets at Kingsgate, British Columbia through its western leg, and also at an international border connection at Monchy, Saskatchewan through its eastern leg. Once again, the connection between the NOVA and Foothills systems is pipe on pipe at what is known as the James River Crossover in central Alberta. NOVA also delivers all the gas transported by the third main export line, Alberta Natural Gas Company Ltd. ("Alberta Natural Gas"), which operates a large diameter pipeline in southeastern British Columbia that transports the gas to the international border, from where it moves through the systems of associated companies to markets in northern California. All three extraprovincial pipeline systems, TCPL, Foothills and Alberta Natural Gas are federal undertakings.

The maximum day capacity of the NOVA system is currently 9.2 billion cubic feet per day with $80 \%$, or 7.4 billion cubic feet, being exported from the province, while the remaining 1.8 billion cubic feet is delivered to points within the province. NOVA has a completely different ownership from TCPL and has its own operating staff consisting of some 2,300 employees.

To date NOVA seems to have led a charmed life since the jurisdiction exercised by the province has never been challenged. Nor does the NEB seem disposed to assert jurisdiction on its own initiative. Nevertheless, the jurisdictional issue could be raised by any shipper on NOVA which is dissatisfied with the way NOVA's tolls are regulated in Alberta $^{29}$ or desires better access to the NOVA system.

The fact that no federal agency has exercised jurisdiction over the NOVA system does not in any way preclude the exercise of such jurisdiction in the future. This was pointed out by Madame Justice Reed in $A G T$ v. $C R T C^{30}$ and her statement that: "The fact that constitutional jurisdiction remains unexercised for long periods of time or is improperly exercised for a long period of time, however, does not mean that there is thereby created some sort of constitutional squatters rights", was expressly endorsed by the Federal Court of Appeal in the Dome case.

The self-evident proposition that the NEB's power to regulate pipelines includes the right to set tolls was confirmed, if any confirmation is needed, in Saskatchewan Power Corporation v. TransCanada PipeLines Limited [1979] 1 S.C.R. 297, [1978] 5 W.W.R. 730, 88 D.L.R. (3d) 289, 23 N.R. 145; [1977] 2 F.C. 324; [1977] 3 W.W.R. 254, 73 D.L.R. (3d) 544, 15 N.R. 63. As to what is included in "tolls" see TransCanada PipeLines Limited v. National Energy Board [1987] 2 W.W.R. 253, 49 Alta. L.R. (2d) 1, 72 N.R. 172, 24 Admin. L.R. 67; C.E.L.S. 10-5137. 
Any analysis of the NOVA situation would have to take into account two seemingly anomalous Supreme Court decisions, which rather unexpectedly upheld provincial jurisdiction, although on very narrow grounds. ${ }^{31}$ In the Kootenay case, a provincially incorporated company proposed to construct a railway south from the Kootenay mining area to the international border where it would almost, but not quite, meet another line to be constructed by an American company a distance of some nine miles from a location in the United States to the international border. Both lines were to stop one-quarter of an inch from the border. It was proposed that trains to the United States company would be brought by its crews to a point north of the border where they would be taken over by Kootenay crews, who would operate the trains to the coal loading points. None of the Kootenay personnel would operate the trains over the border or in the United States.

A divided Supreme Court found that the British Columbia Legislature was not precluded from authorizing the incorporation of a company to construct the railway line which would be wholly situate within the borders of the province. However, Martland, J., speaking for the majority, went on to point out that "when the two lines are joined", i.e. when trains are operated over them, an overall undertaking of international character may emerge. The Kootenay case is also noteworthy for the strong dissent of Hall, J. which was later described by Laskin, C.J.C. as "cogent". ${ }^{32}$ Justice Hall was clearly offended by what he found to be a subterfuge on the part of those who proposed to incorporate the railway line under provincial legislation. He pointed out that there never was the slightest intention on their part that the Kootenay railway would be a wholly contained provincial undertaking with an operation beginning and ending in British Columbia. As he put it:

Throughout the argument the unreality of the whole situation became crystal clear that the Court was being called upon to deal with the wholly fictitious situation dressed up in legalistic terminology and argument involving corporate powers to obscure the realities of what was being proposed. ${ }^{33}$

In refusing to look only at the current situation, Hall, J. was taking the same approach as would later be followed by the Federal Court of Appeal in the Dome case, where the Court expressly approved the NEB taking future changes into account.

Even the majority decision, however, does not lend any real support to provincial jurisdiction over the NOVA gathering network. The court recognized that once the railway lines were placed in operation, an international undertaking would likely emerge. In the case of NOVA, the gas which is transported through its gathering system continues its extraprovincial journeys through the three mainline systems which would suggest that an extraprovincial undertaking has "emerged". Furthermore, the connection between the NOVA and the three federal pipeline undertakings is pipe on pipe and the flow of natural gas is continuous.

31. Kootenay \& Elk Railway Company v. Canadian Pacific Railway [1974] S.C.R. 955, (1972) 28 D.L.R. (3d) 385 (S.C.C.) and Fulton et al v. Energy Resources Conservation Board et al, supra, note 2.

32. Fulton et al, supra, note 2 at 245.

33. Kootenay, supra, note 31, D.L.R. at 417. 
In the second rather anomalous decision, Fulton v. Alberta Energy Resources Conservation Board et al., it was held that the provincial Board could authorize the construction and operation of an electrical transmission line to the Alberta/British Columbia border where it would interconnect with the British Columbia electrical facilities. In upholding the jurisdiction of the Provincial Board, the Supreme Court relied on the fact that there was no existing federal regulatory authority that covered the situation. Moreover, the applicant did not challenge the regulatory power of Parliament at the point of interprovincial interconnection if the federal government chose to act. The Court pointed out that the NEB was not vested with regulatory authority that would bring the project under its control. Laskin, C.J.C. stated that:

The prospect of a federal legislative interest when an interconnect is made with facilities in British Columbia is not enough to bring this case within s. 92(10)(a) when there is no applicable federal legislation. $^{34}$

It seems a reasonable inference that, had there been applicable federal legislation, the court might well have reached the opposite conclusion. In the case of NOVA, it is clear that the NEB has more than ample powers over the regulation of pipelines. Thus, both the Kootenay and Fulton cases, which at first blush may appear to support provincial jurisdiction over a system such as NOVA, are so limited in scope as to be of no assistance. Indeed, if anything, the rationale of these decisions would tend to support federal jurisdiction.

Paradoxically, the sheer size and importance of NOVA's pipeline operations may be its best defence against the imposition of federal jurisdiction. After looking at the whole picture, a court might conclude that an operation which employs more than 2,000 people and is capable of collecting and transporting more than 9 billion cubic feet of gas per day is a distinct and separate undertaking on its own. The fact that $20 \%$ of the gas is delivered to points within the province might also make a court hesitate before finding that the NOVA system formed part of a federal undertaking such as TCPL. Even more significant is the fact that NOVA delivers Alberta gas not just to TCPL, but to a number of extraprovincial lines that serve markets in the United States and other parts of Canada. This would tend to fortify the conclusion that collecting natural gas throughout the Province and delivering it to a number of export points is an undertaking complete unto itself.

In the final analysis, however, it is difficult to see how NOVA could avoid the consequences of the "essential" test. The three extraprovincial pipelines, all of which are federal undertakings, simply cannot function without the natural gas which is delivered to them by the NOVA system. Without that gas, Foothills and Alberta Natural Gas would have nothing to transport and TCPL would be left with a reduced throughput that would be completely uneconomic. Thus, the NOVA system, in relation to these federal undertakings, goes beyond being essential to being indispensable. 
The political fallout from any judicial ruling that NOVA forms an integral part of one or more federal undertakings would be horrendous. Unless one of the periodic energy wars between Ottawa and Alberta happened to be raging at the time, the parties might opt for a political solution, à la Winner. Under this scenario, the federal government would delegate regulatory powers over NOVA to an Alberta board.

In some respects, the British Columbia pipeline operations of Westcoast Energy Inc. ("Westcoast") parallel those of NOVA, although in other respects they differ markedly. The Westcoast facilities primarily consist of pipelines that extend into the Northwest Territories and Alberta (the flow in the lines extending into Alberta can be reversed so that British Columbia gas can flow into the NOVA system, as well as Alberta gas being able to flow into the Westcoast system); three large gas processing plants located in northern British Columbia; and large diameter transmission lines that transport gas to both domestic British Columbia and export markets. Approximately $60 \%$ of the gas transported through the Westcoast system goes to domestic sales, with the remaining $40 \%$ being exported to markets in the Pacific Northwest at a point near Huntingdon, British Columbia. While there have been suggestions that because of the large volumes of gas transported by Westcoast between points within British Columbia, it should be regulated by the province, its present configuration, with lines extending beyond British Columbia and into the Territories and Alberta makes it a federal undertaking of the "primary instance" type. It is interesting to speculate what steps, if any, might be taken to bring at least a portion of its operations within provincial jurisdiction. The processing plants would seem like a good place to start.

If there is a chance that the NOVA gathering system might be held to be an integral part of a federal undertaking, what then of the local distribution companies, such as Consumers' and Union, that deliver the gas to the end-users? Facilities at the end of, or at take-off points on a federal pipeline undertaking may well be constitutionally different from facilities at the upstream end of the system, which deliver the hydrocarbons to be transported by the federal pipeline. This difference was reflected in the Cyanamid case which can usefully be compared to Westspur, where a gathering system within Saskatchewan was found to be integral to a federal oil pipeline. On a more fundamental level, a court might well find the that the "undertaking" of a federal pipeline such as TCPL is to deliver gas produced in western Canada to markets in the east, and that this undertaking would be complete when the gas was delivered into the market area. Thus the distribution aspect could be treated as an entirely different undertaking and one not subject to federal jurisdiction.

\section{THE "ESSENTIAL" TEST AND RELATED PIPELINE SERVICES}

This paper has focused on facilities rather than services, partly because the three recent Federal Court pipeline cases involved facilities, and also because jurisdiction over facilities is likely to be much more significant than is the case with services. Jurisdiction over services usually involves such questions as which labour legislation will apply to the employees, while facilities involve jurisdiction over the physical plant itself. However, the "essential" test would seem equally applicable to determining whether the necessary nexus exists between a service (such as trucking crude oil to a federal pipeline terminal) 
and the federal undertaking. It will probably prove to be more difficult to establish the necessary nexus with services since, as a general rule, they will not be as closely linked with the undertaking as will facilities. ${ }^{35}$

For example, a storage terminal where crude oil is collected prior to being batched down an extraprovincial pipeline is clearly part of that federal undertaking. On the other hand, a trucking company which transports crude oil from wells in the province to destinations within the province, such as refineries, and which also transports crude oil to the pipeline terminal would not, in all likelihood, form part of the extraprovincial pipeline undertaking.

However, some situations may lead to a service being held to comprise an extraprovincial undertaking within the meaning of MacGuigan, J.'s "primary instance", which corresponds to what I have termed category (i). Here, exclusivity and ownership may become all-important. If the sole business of the trucking company is to deliver crude to that pipeline terminal, and if the company were owned by the federal undertaking, it might well be found to comprise a part of the federal undertaking.

\section{CONCLUSION}

The "essential" test has much to recommend it. For one thing, it conforms more closely to the realities of the situation than some other factors that courts have looked to in the past. While it is necessarily judgmental, the question of whether or not a facility is truly essential to the operation of a pipeline system lends itself to proof by evidence and the application of common sense. Philosophically, it also seems appropriate that something which is essential to the operation of an undertaking should be treated as an integral part of that undertaking. 